\title{
Mental Practice untuk Menurunkan Kecemasan: Sebuah Meta-Analisis
}

\author{
Prastika Prima Nugraheni, Ananta Yudiarso \\ Universitas Surabaya
}

\begin{abstract}
Mental Practice (Relaxation, Imagery, and Self Talk has an inconsistent impact on reducing anxiety in previous studies. This study aims to determine the level of effectiveness of Mental Practice interventions to reduce anxiety. In this case, a review was carried out to 17 journals related to Mental Practice (Relaxation, Imagery, and Self Talk) with a total number of 1054 participants; 521 people in the Experiment group, and 533 people in the Control group. Data processing is based on the number of sample size (N), mean (M), and standard deviation (SD), and by using the Random Effect Model criteria, the result of Hedges $g$ is 1.19. From the result, it can be concluded that Mental Practice has a great effect in reducing someone's anxiety.

Keyword: Mental Practice; Anxiety; Meta-Analysis
\end{abstract}

\begin{abstract}
Abstrak
Mental Practice (Relaksasi, Imagery dan Self Talk) memiliki dampak yang tidak konsisten terhadap penurunan kecemasan di penelitian sebelumnya. Penelitian ini memiliki tujuan untuk mengetahui tingkat efektivitas intervensi Mental Practice (Relaksasi, Imagery dan Self Talk) dalam rangka menurunkan kecemasan. Pada penelitian ini dilakukan reviu terhadap 17 jurnal yang berkaitan dengan Mental Practice Total partisipan adalah 1054 dengan rincian 521 orang masuk ke dalam Kelompok Eksperimen sedangkan 533 orang masuk ke dalam Kelompok Kontrol. Pengolahan data berdasarkan jumlah sample size $(\mathrm{N})$, mean $(\mathrm{M})$ dan standar deviasi (SD) menggunakan kriteria Random Effect Model memperoleh nilai Hedges g sebesar 1,19. Berdasarkan hasil tersebut maka dapat disimpulkan bahwa Mental Practice memiliki efek yang besar terhadap penurunan kecemasan seseorang.
\end{abstract}

Kata Kunci : Pelatihan Mental; Kecemasan; Meta-Analisis

Kecemasan adalah hal yang semua manusia pernah alami. Spielberger,1972 (Sakeroglu, 2017) mengartikan kecemasan sebagai suatu reaksi emosional yang mengganggu atau tidak 
nyaman pada hal yang secara nyata membahayakan atau pada hal yang hanya ada dalam pikiran atau imajinasi seseorang saja. Kecemasan dapat didefinisikan sebagai situasi emosi yang mampu memunculkan keterangsangan secara fisiologis, rasa tegang yang tidak nyaman dan dapat kegelisahan mengenai hal negatif yang akan terjadinya (Nevid et al., 2014). Spielberger,1972 (Sakeroglu, 2017) mengungkapkan biasanya kecemasan ditandai dengan adanya perubahan di syaraf otonom dan pengalaman subyektif seseorang seperti tekanan, permusuhan atau kegelisahan.

Spielberger,1972 (Lin et al., 2011); Sakeroglu, 2017) menuturkan ada dua jenis kecemasan yakni Trait Anxiety dan State Anxiety. Trait anxiety didefinisikan sebagai kecemasan yang muncul akibat dari kepribadian individu yang mempunyai tendensi lebih pencemas jika dibanding orang pada umumnya. Kecemasan tersebut muncul ditandai dengan adanya rasa khawatir atau terancam pada kondisi yang bahkan secara obyektif tidak berbahaya. State anxiety didefinisikan sebagai situasi emosional individu yang bersifat sementara. Situasi emosional tersebut ditandai dengan adanya kekhawatiran dan ketegangan yang individu rasakan secara sadar dan sifatnya subyektif.

Spilberger, 1972 (Sakeroglu, 2017) menyatakan bahwa kecemasan memiliki dua komponen yaitu cognitive anxiety dan somatic anxiety. Cognitive Anxiety merupakan komponen mental yang memperlihatkan adanya kecenderungan mengenai sejauh mana individu khawatir atau memikirkan pikiran negatifnya. Cognitive Anxiety ini muncul karena terdapat ekspektasi negatif atas harapan atau evaluasi negatif yang individu berikan. Komponen selanjutnya yakni Somatic Anxiety komponen ini merujuk kepada perubahan fisiologis yang dirasakan oleh individu karena adanya kecemasan. Misalnya jantung berdebar lebih cepat, keringan bercucuran dan lain sebagainya. Selain itu persepsi seseorang terhadap adanya perubahan tersebut juga masuk dalam kategori Somatic Anxiety contoh rasa pusing, mual, sakit perut yang individu rasakan ketika sedang dalam keadaan cemas.

Penelitian sebelumnya menyatakan bahwa kecemasan yang tidak tertangani dengan baik dapat menimbulkan beragam efek negatif pada individu. Kecemasan yang meningkat bisa 
menyebabkan prosedur endoskopi tidak bisa dijalankan secara utuh (Shamekhi et al., 2019), memberikan dampak negatif pada kualitas hidup pasien (Zhou, 2014) dan mengganggu proses pembelajaran mahasiswa (Carver \& O'Malley, 2015). Selain itu Thom dan Zeeman, 1974 (Dali \& A. Parnabas, 2018) menyatakan bahwa peningkatan cognitive anxiety akan menimbulkan peningkatan gairah fisiologis yang akan membawa kinerja ke arah yang lebih buruk.

Ada berbagai cara yang dapat digunakan untuk mengurangi kecemasan salah satunya adalah dengan mengembangkan Mental Practice. Mental Practice dapat digunakan sebagai sarana untuk melatih mental seseorang agar lebih siap untuk menanggung beban psikologisnya. Lismadiana (2014) mengungkapkan bahwa ketika individu tidak memiliki kesiapan mental yang baik, maka kemungkinan besar ia tidak akan dapat menanggung beban mental yang seharusnya bisa ditanggung. Individu dengan mental yang lebih tangguh cenderung memiliki kecemasan yang lebih rendah dari pada mereka yang tidak (Schaefer, 2016; Kristjansdottir, 2018)

Setidaknya ada 3 jenis Mental Practice antara lain adalah Relaksasi, Imagery dan Self Talk (Weinberg \& Gould, 2011). Relaksasi memungkinakan individu untuk menurunan ketegangan otot, ketegangan otot yang menurun akan menurunkan ketegangan mental pula. Imagery adalah intervensi yang mengarah pada proses visualisasi dalam pikiran tentang suatu obyek, peristiwa, atau gerakan tertentu yang kemudian disimpan dalam ingatan sebelum akhirnya diterapkan pada kondisi nyata (Nurfalah et al., 2016). Serta Self Talk, dialog yang individu lakukan dengan dirinya sendiri yang bertujuan untuk menafsirkan perasaan dan atau persepsinya, mengevaluasi (merubah) keyakinan, memberikan instruksi dan atau penguatan pada dirinya sendiri.

Akan tetapi penelitian yang ada menunjukan adanya inkonsistensi pada hasil dari penerapan Mental Practice tersebut. Beberapa penelitian menunjukan bahwa Mental Practice tersebut efektif untuk menurunkan kecemasan (Choi, 2010; Liu et al., 2020; Mizrahi et al., 2012) sedangkan pada penelitian yang lain tidak ditemukan hasil yang serupa (Carver \& O'Malley, 2015; Premananda \& Bhowmik, n.d.; Tavakolizadeh et al., 2018). Kondisi inkonsisten tersebut 
menjadi dasar bagi peneliti untuk menguji mengenai seberapa besar Mental Practice memiliki dampak dalam upaya menurunkan kecemasan.

Hasil penelitian ini diharapkan bisa memberikan manfaat teoretis antara lain sebagai referensi bagi penelitian yang akan datang terkait dengan topik yang terkait dengan pelatihan mental maupun kecemasan serta dapat digunakan sebagai bahan kajian di ranah psikologi di masa yang akan datang. Selain itu penelitian ini juga diharapkan dapat memberikan manfaat praktis berupa penambahan wawasan bagi para pembaca, sebagai salah satu bukti mengenai keefektifan pelatihan mental dalam upaya mengurangi kecemasan serta sebagai pertimbangan dalam pengamplikasian pelatihan mental dalam upaya menurunkan kecemasan.

\section{Metode}

\section{Sumber Data}

Sumber data dari penelitian ini adalah berbagai artikel penelitian sebelumnya yang berjumlah 17 artikel penelitian yang terkait dengan pelatihan mental serta kecemasan. Artikel penelitian tersebut merupaka artikel penelitian dengan metode eksperimen dengan kelompok kontrol yang mengujikan berbagai jenis pelatihan mental dalam upayanya untuk mengurangi kecemasan. Berbagai artikel penelitian tersebut diperoleh melalui pencarian di laman Google Scholar sesuai dengan kriteria yang telah ditetapkan.

\section{Metode Meta analisis}

Meta analisis diartikan sebagai suatu proses pengintegrasian berbagai hasil penelitian secara numerik hingga mampu untuk memunculkan suatu bukti sintesis dalam bentuk perkiraan ringkasan (Basu, n.d.). Adapun langkah-langkah yang dilakukan dalam penelitian ini adalah sebagai berikut. Pertama, penelitian ini dimulai dengan mencari penelitian yang relevan melalui pencariaan kata kunci di laman Google Schoolar. Adapun kata kunci yang digunakan adalah "mental practice dan anxiety". Kedua, setelah berbagai artikel tersebut terkumpul, peneliti melakukan penyaringan kembali berdasarkan kriteria inklusi sebagai berikut (1) memuat variabel Mental Practice dan Anxiety (2) tahun publikasi jurnal kurang lebih 10 tahun 
belakangan (3) menggunakan metode penelitian Experiment Control Group Design. (4) memuat mean dan srandar deviasi dari kelompok eksperimen dan kelompok control serta (5) Alat ukur variabel Anxiety menggunakan spielberger state anxiety inventory.

Ketiga, peneliti memasukan data dari setiap jurnal yang telah memenuhi kriteria ke dalam website daring pengolahan data meta-analisis yakni Meta-mar (http://www.meta-mar.com). Keempat hasil dari pengolahan data kemudian dianalisis oleh peneliti. Berdasarkan hasil pengolahan data pada website tersebut ditemukan nilai Heterogenity $\left(\mathrm{I}^{2}\right)$ dan hedges'g. HeudoMedina and Colleagues (Card, n.d.) menyebutkan bahwa nilai $\mathrm{I}^{2}$ memiliki tiga kategori yakni rendah $\left(\mathrm{I}^{2}=25 \%\right)$, sedang $\left(\mathrm{I}^{2}=50 \%\right)$ dan tinggi $\left(\mathrm{I}^{2}=75 \%\right)$. Hasil pengolahan data menunjukan bahwa nilai $\mathrm{I}^{2}$ lebih dari 75\% karena itu maka dalam penelitian ini yang digunakan adalah Random Effect Size Model. Random Effect Size Model menunjukan nilai Inconsistency (I²) adalah sebesar $92 \%$. Kemudian terkait dengan effect size intervensi pengolahan data yang dilakukan berdasarkan atas nilai dari Standart Deviasi (SD), jumlah partisipan (N), dan Mean (M) masingmasing kelompok. Lalu yang menjadi tolok ukur pengelompokan tingkat effect size adalah hedges'g yang muncul. Terdapat tiga kategori dalam menilai tingkat effect size yakni small effect size $(0.2 \leq \mathrm{g}<0.5)$, medium effect size $(0.5 \leq \mathrm{g}<0.8)$ dan large effect size $(\leq 0.8)($ Ellis, 2010).

\section{Hasil}

Artikel penelitian dicari dengan kata kunci Imagery, Relaxation, Self Talk and Anxiety dalam rentang waktu sepuluh tahun belakangan di laman Google Scholar. Pencarian tersebut menunjukan terdapat 22.600 artikel penelitian dan buku yang terkait dengan kata kunci tersebut. Setelah itu pencarian difokuskan pada penelitian yang menggunakan metode eksperimen sehingga didapatkan kurang lebih 17.800 artikel penelitian yang membahas mengenai kata kunci tersebut dengan metode eksperimen. Pencarian kemudian kembali dilanjutkan dengan mulai menyaring penelitian tersebut berdasarkan kesamaan alat ukur kecemasan yang dipakai. Dari seleksi tersebut diperoleh 1.470 jurnal yang menggunakan alat ukur kecemasan yang sama yakni dengan Spielberger State Trait Anxiety Inventory. Artikel 
penelitian yang diperoleh tersebut kemudian kembali dicek hingga diperoleh 27 artikel yang menggunakan desain eksperimen pre-post control group design. Penelitian yang diperoleh tersebut kemudian diperiksa kembali terkait dengan kelengkapan komponen-komponen yang diperlukan untuk menghitung effect sizenya seperti mean, standar deviasi dan jumlah sampel dari kelompok eksperimen dan kelompok kontrol yang ada di dalamnya. Artikel penelitian yang menggunakan metode eksperimen satu grup, menggunakan alat ukur kecemasan selain Spielberger State Trait Anxiety Inventory serta tidak mencantumkan mean, standar deviasi dan jumlah sampel dari kelompok eksperimen dan kelompok kontrol yang ada di dalamnya tidak dapat digunakan karena memenuhi kriteria eksklusi.

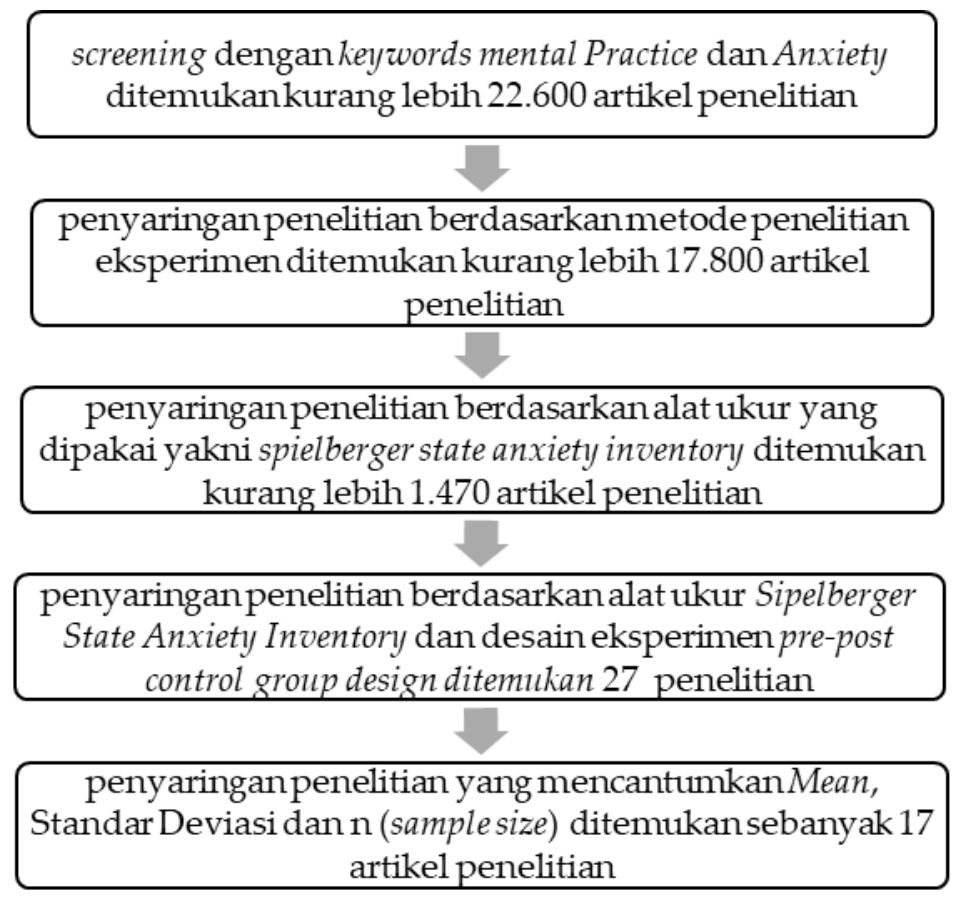

\section{Bagan 1. Proses Literatur Review}

Total partisipan dalam penelitian adalah sebanyak 1054 orang dengan rincian 521 berada dalam Kelompok Eksperimen dan 533 orang pada Kelompok Kontrol. Nilai Inconsistency sebesar $92 \%>75 \%$ menunjukan tingkat keberagaman data yang tinggi (Bruce, n.d.). Hal tersebut membuat nilai Hedges g yang digunakan adalah pada kategori Random Effect Model. Nilai Hedges g pada kategori Random Effect Mode memperlihatkan angka sebesar 1,19 dengan begitu berarti Mental Practice memiliki tingkat effect size dengan ketegori large effect size terhadap kecemasan. 
Data dengan keberagaman yang tinggi kemungkinan disebabkan oleh beberapa hal antara lain perbedaan jenis kelamin paartisipan, usia partisipan yang beragam serta negara tempat dilaksanakannya penelitian yang berbeda-beda. Nilai $\mathrm{p}$ value pada Random Effect Model menunjukan angka 0,00002<0,0001 dengan begitu dapat dikatakan bahwa dalam hal ini tidak ada bias publikasi. Berikut merupakan kalkulasi atau tabel meta-analisis size effect untuk setiap penelitian yang ditemukan.

Tabel 1.

Hasil Kalkulasi Effect Size

\begin{tabular}{|c|c|c|c|c|c|c|c|c|}
\hline Peneliti & Metode & Alat ukur & G & SEg & g_lower & g_upper & $\begin{array}{l}\text { Weight } \\
(\%) \text {-fixed } \\
\text { model }\end{array}$ & $\begin{array}{l}\text { Weight } \\
(\%)- \\
\text { random } \\
\text { model }\end{array}$ \\
\hline $\begin{array}{l}\text { Mizrahi et } \\
\text { al, } 2012\end{array}$ & Relaksasi & $\begin{array}{l}\text { Spielberger } \\
\text { State } \\
\text { Anxiety } \\
\text { Inventory }\end{array}$ & 0,320769 & 0,316742 & $-0,30005$ & 0,941583 & 4,5801 & 5,9954 \\
\hline $\begin{array}{l}\text { Zhou et al, } \\
2015\end{array}$ & Imagery & $\begin{array}{l}\text { Spielberger } \\
\text { State } \\
\text { Anxiety } \\
\text { Inventory }\end{array}$ & 1,730889 & 0,179252 & 1,379556 & 2,082222 & 14,30103 & 6,417888 \\
\hline $\begin{array}{l}\text { Foji et al, } \\
2015\end{array}$ & Relaksasi & $\begin{array}{l}\text { Spielberger } \\
\text { State } \\
\text { Anxiety } \\
\text { Inventory }\end{array}$ & 7,930149 & 0,755024 & 6,450301 & 9,409997 & 0,806068 & 4,125298 \\
\hline $\begin{array}{l}\text { Yilmaz dan } \\
\text { Arslan, } \\
2015\end{array}$ & Relaksasi & $\begin{array}{l}\text { Spielberger } \\
\text { State } \\
\text { Anxiety } \\
\text { Inventory }\end{array}$ & 0,854455 & 0,266515 & 0,332085 & 1,376825 & 6,469186 & 6,169937 \\
\hline $\begin{array}{l}\text { Song et al, } \\
2013\end{array}$ & Relaksasi & $\begin{array}{l}\text { Spielberger } \\
\text { State } \\
\text { Anxiety } \\
\text { Inventory }\end{array}$ & 1,328517 & 0,219575 & 0,898149 & 1,758884 & 9,530745 & 6,313 \\
\hline Choi, 2010 & Imagery & $\begin{array}{l}\text { Spielberger } \\
\text { State } \\
\text { Anxiety } \\
\text { Inventory }\end{array}$ & 0,128289 & 0,202703 & $-0,26901$ & 0,525586 & 11,18343 & 6,359043 \\
\hline $\begin{array}{l}\text { Gholamrez } \\
\text { a \& Aziz, } \\
2016\end{array}$ & Self Talk & $\begin{array}{l}\text { Spielberger } \\
\text { State } \\
\text { Anxiety } \\
\text { Inventory }\end{array}$ & 2,444499 & 0,576927 & 1,313721 & 3,575276 & 1,380549 & 4,89665 \\
\hline
\end{tabular}




\begin{tabular}{|c|c|c|c|c|c|c|c|c|}
\hline $\begin{array}{l}\text { Dali \& } \\
\text { Parnabas, } \\
2018\end{array}$ & Self Talk & $\begin{array}{l}\text { Spielberger } \\
\text { State } \\
\text { Anxiety } \\
\text { Inventory }\end{array}$ & 0,496208 & 0,400625 & $-0,28902$ & 1,281432 & 2,86298 & 5,666415 \\
\hline $\begin{array}{l}\text { Hoffman } \\
\text { dan } \\
\text { Hanrahan , } \\
2012\end{array}$ & Imagery & $\begin{array}{l}\text { Spielberger } \\
\text { State } \\
\text { Anxiety } \\
\text { Inventory }\end{array}$ & 0,250311 & 0,342465 & $-0,42092$ & 0,921543 & 3,917977 & 5,898957 \\
\hline $\begin{array}{l}\text { Paremanan } \\
\text { da dan } \\
\text { Bowmik, } \\
2017\end{array}$ & $\begin{array}{l}\text { Self Talk } \\
\text { dan } \\
\text { Relaksasi }\end{array}$ & $\begin{array}{l}\text { Spielberger } \\
\text { State } \\
\text { Anxiety } \\
\text { Inventory }\end{array}$ & $-0,55756$ & 0,259879 & $-1,06692$ & $-0,04819$ & 6,803822 & 6,191419 \\
\hline $\begin{array}{l}\text { Shamekhi } \\
\text { et al, } 2019\end{array}$ & Imagery & $\begin{array}{l}\text { Spielberger } \\
\text { State } \\
\text { Anxiety } \\
\text { Inventory }\end{array}$ & 1,245852 & 0,262492 & 0,731368 & 1,760337 & 6,669017 & 6,183007 \\
\hline $\begin{array}{l}\text { Tavakoliza } \\
\text { deh et al, } \\
2018\end{array}$ & Imagery & $\begin{array}{l}\text { Spielberger } \\
\text { State } \\
\text { Anxiety } \\
\text { Inventory }\end{array}$ & 0,39411 & 0,281176 & $-0,15699$ & 0,945215 & 5,812164 & 6,121122 \\
\hline Zhao, 2012 & Relaksasi & $\begin{array}{l}\text { Spielberger } \\
\text { State } \\
\text { Anxiety } \\
\text { Inventory }\end{array}$ & 2,281851 & 0,274126 & 1,744565 & 2,819138 & 6,114961 & 6,144825 \\
\hline $\begin{array}{l}\text { Carver dan } \\
\text { O'Malley, } \\
2015\end{array}$ & Relaksasi & $\begin{array}{l}\text { Spielberger } \\
\text { State } \\
\text { Anxiety } \\
\text { Inventory }\end{array}$ & 0,723926 & 0,504718 & $-0,26532$ & 1,713174 & 1,803833 & 5,217885 \\
\hline $\begin{array}{l}\text { Liu et al, } \\
2020\end{array}$ & Relaksasi & $\begin{array}{l}\text { Spielberger } \\
\text { State } \\
\text { Anxiety } \\
\text { Inventory }\end{array}$ & 1,085271 & 0,295995 & 0,505121 & 1,665422 & 5,244751 & 6,069966 \\
\hline Pan, 2012 & Relaksasi & $\begin{array}{l}\text { Spielberger } \\
\text { State } \\
\text { Anxiety } \\
\text { Inventory }\end{array}$ & 1,084019 & 0,237519 & 0,618482 & 1,549555 & 8,145149 & 6,260818 \\
\hline $\begin{array}{l}\text { Charette et } \\
\text { al } 2015\end{array}$ & Imagery & $\begin{array}{l}\text { Spielberger } \\
\text { State } \\
\text { Anxiety } \\
\text { Inventory }\end{array}$ & 0,715615 & 0,324115 & 0,080349 & 1,350881 & 4,374162 & 5,968276 \\
\hline
\end{tabular}




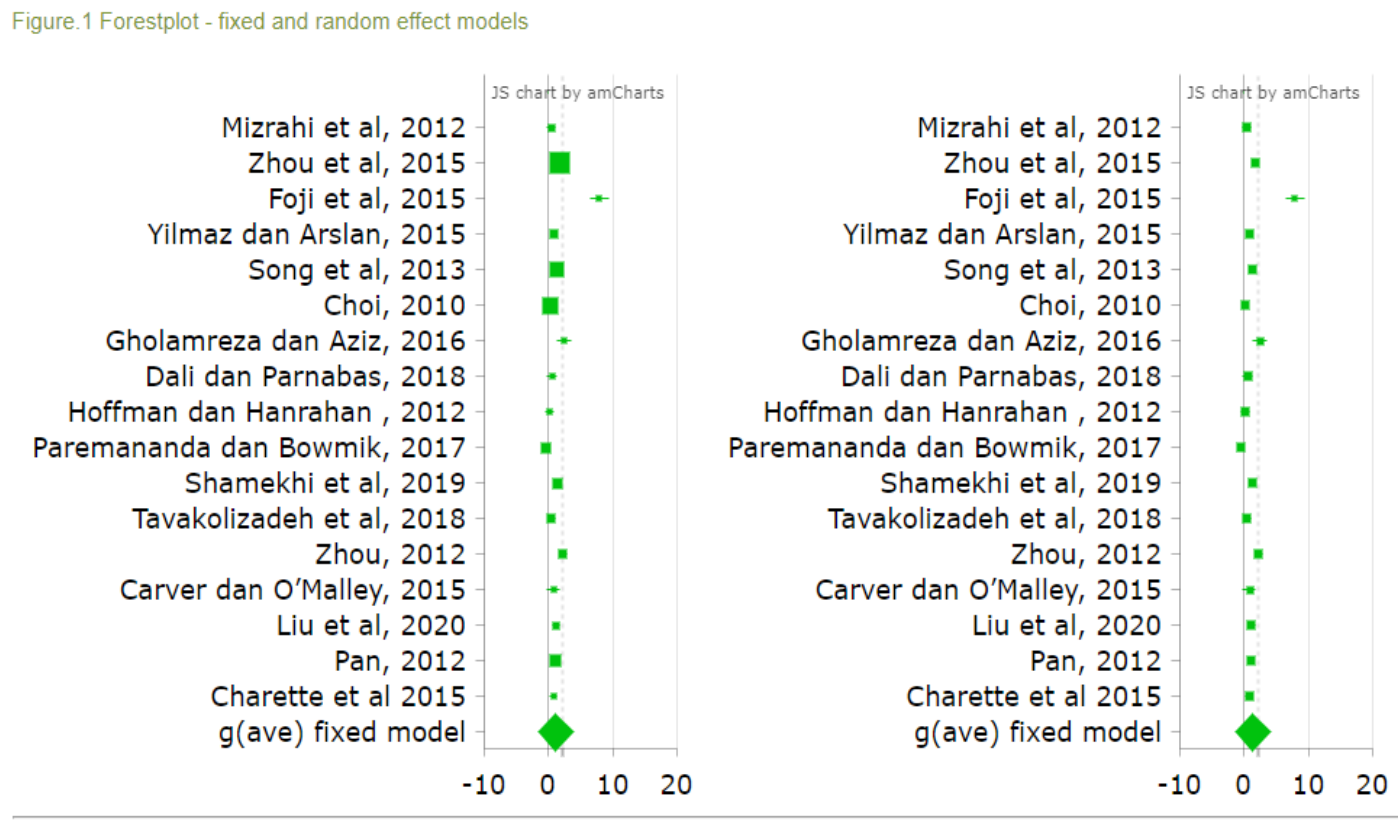

\section{Gambar 1. Foresplot Fixed dan Random Model}

Nilai Hedges g yang diperoleh adalah sebesar 1,19. Nilai tersebut memiliki arti bahwa Mental Practice memiliki large effect size terhadap kecemasan. Prosentase jumlah penelitian yang menunjukan adanya large effect size dari Mental Practice terhadap kecemasan adalah sebesar 58,8\%, penelitian dengan tingkat effect size medium to high sebanyak 5,8\%, kemudian 23,5\% diantaranya menunjukan adanya low to medium effect size dan 11,8\% memperlihatkan bahwa Mental Practice memiliki low effect size terhadap kecemasan.

\section{Pembahasan}

Pada bidang olahraga intervensi Mental Practice dalam mengatasi kecemasan lebih efektif dilakukan untuk olahraga yang bersifat nonkompetitif (Gholamreza \& Aziz, 2016; Dali \& A. Parnabas, 2018) sedangkan untuk olahraga kompetitif Mental Practice dianjurkan untuk dilakukan selama latihan baik saat offseason atau preseason (Premananda \& Bhowmik, n.d.). Hal tersebut dilakukan dengan harapan selama kompetisi sedang berjalan atlet sudah bisa memperoleh hasil dari latihan mental yang ia alami sebelumnya.

Selanjutnya di bidang kesehatan Mental Practice memiliki andil pada penurunan kecemasan pasien dengan kanker payudara (Song et al., n.d.; Yilmaz et al., 2015; Zhao et al., 2012). Selain itu dampak yang besar terhadap penurunan kecemasan juga dirasakan pada 
pasien dengan penyakit jantung yang akan melakukan scan jantung (Foji, 2015), pasien yang akan melakukan prosedur endoskopi (Shamekhi et al., 2019), pasien dengan endometriosis (Zhao et al., 2012), pasien dengan kehamilan ektopik (Pan et al., 2012)dan pasien yang positif terinfeksi virus COVID-19 (Liu et al., 2020). Tidak hanya pada pasien namun Mental Practice juga mampu menurunkan kecemasan para pengasuh dari pasien yang menjalani rawat inap (Liu et al., 2020). Akan tetapi untuk pasien dengan sindrom koroner akut yang mengalami intervensi dalam waktu singkat (Tavakolizadeh et al., 2018) dan pasien dengan penyakit radang usus (Mizrahi et al., 2012) Mental Practice belum bisa memberikan dampak yang baik pada kecemasan.

Di bidang musik Mental Practice lebih cocok digunakan untuk performer yang tidak memiliki diagnosa lain selain performance anxiety (Hoffman \& Hanrahan, n.d.). Di bidang pendidikan Mental Practice memberikan penurunan kecemasan yang cukup besar pada mahasiswa semester akhir di salah satu universitas di Alaska (Carver \& O’Malley, 2015).

Berdasar pelaksanaannya, Mental Practice yang dilakukan setiap hari cenderung akan memiliki dampak lebih besar pada kecemasan (Foji, 2015; Liu et al., 2020; Pan et al., 2012; Zhao et al., 2012). Mental Practice yang dilakukan setidaknya selama tiga kali dalam satu minggu dengan durasi selama 50 menit persesi sudah akan mampu memberikan efek positif pada kecemasan (Yilmaz et al., 2015). Akan tetapi jika ingin lebih optimal bisa dilakukan setiap hari dengan durasi selama 18 menit di setiap harinya khususnya dalam penerapan Imagery (Foji, 2015).

Berdasarkan usia, Mental Practice sudah bisa diterapkan dengan baik pada remaja dengan usia minimal 13 tahun (Gholamreza \& Aziz, 2016). Menurut tahapan perkembangan Piaget pada usia tersebut remaja telah berada pada tahap perkembangan kognitif operasional formal. Tahap ini memungkinkan remaja untuk memikirkan hal-hal yang sifatnya lebih abstrak. Secara lebih lanjut Piaget menjelaskan bahwa kemampuan abstraksi yang sudah dimiliki akan memampukan remaja untuk membayangkan dan menyelesaikan permasalahan yang disajikan secara verbal (Khiyarusoleh \& Pd, 2016). 


\section{Kesimpulan}

Proses pengolahan data menunjukan bahwa Mental Practice (Imagery, Relaxation dan Self Talk) memiliki large effect size $(1,19)$ terhadap kecemasan baik itu kecemasan yang terjadi pada pasien dengan sakit fisik, atlet atau partisipan di ranah olahraga maupun kinerja individu pada bidang lain. Kesimpulan tersebut memberikan implikasi bahwa penelitian yang dilakukan mampu untuk menjadi salah satu bukti efektifnya pelatihan metal dalam upaya untuk menurunkan kecemasan yang terjadi di berbagai macam setting atau ranah. Berdasarkan hal tersebut maka diharapkan metode mental practice dapat coba diaplikasikan atau dilatihkan pada berbagai ranah untuk bisa membantu mengurangi kecemasan yang timbul. Misalnya dalam ranah kesehatan, diaplikasikannya metode mental practice dapat menjadi pilihan yang bagus untuk mencoba mengurangi kecemasan pasien dalam menghadapi tindakan medis yang akan dilakukan atau dalam ranah olahraga dimana metode mental practice dapat membantu atlet untuk mengurangi kecemasan agar dapat menjadi lebih siap menghadapi suatu pertandingan.

Akan tetapi berdasarkan proses yang telah dilalui penelitian ini memiliki beberapa kelemahan. Kelemahan tersebut antara lain (1) Metode mental practice pada penelitian ini pada dasarnya beragam antara lain Imagery, Relaxation dan Self Talk (2) Penelitian yang menjadi sumber data berasal dari beragam negara dengan latarbelakang budaya yang berbeda-beda (3) Variabel Anxiety yang terlalu beragam sehingga kurang spesifik (4) Jumlah jurnal penelitian yang digunakan sebagai sumber data terbatas.

\section{Saran}

Berdasarkan hasil penelitian mengenai pelatihan mental dan pengaruhnya terhadap kecemasan yang telah dilaksanakan ada beberapa saran yang dapat diberikan untuk penelitian selanjutnya. Penelitian selanjutnya diharapkan untuk lebih memperhatikan beberapa hal berikut agar kesimpulan effect size yang ditegakkan menjadi semakin kuat. (1) Peneliti selanjutnya diharapkan dapat lebih fokus pada salah satu metode pelatihan mental (2) Artikel penelitian yang digunakan sebagai sumber data lebih baik berasal dari negara dengan latarbelakang 
budaya yang relatif memiliki kesamaan (3) Variabel dependen yang digunakan diharapkan bisa lebih spesifik lagi (4) Menggunakan lebih banyak jurnal penelitian sebagai sumber data.

\section{Referensi}

Basu, A. (n.d.). How to Conduct Meta-Analysis: A basic Tutorial. 15.

Bruce, N. (n.d.). Quantitative Methods for Health Research. 554.

Card, N. (n.d.). Applied Meta-Analysis for Social Science Research. 402.

Carver, M. L., \& O’Malley, M. (2015). Progressive Muscle Relaxation To Decrease Anxiety In Clinical Simulations. Teaching and Learning in Nursing, 10(2), 57-62.

Choi, Y. K. (2010). The Effect of Music and Progressive Muscle Relaxation on Anxiety, Fatigue, and Quality of Life in Family Caregivers of Hospice Patients. Journal of Music Therapy, 47(1), 53-69.

Dali, M. S., \& A. Parnabas, V. (2018). The Effects of Self-Talk On Free Throw Performance and The Level of Anxiety Among Male Novice Basketball Players. MoHE, 7(1).

Ellis, P. D. (2010). The Essential Guide to Effect Sizes: Statistical Power, Meta-Analysis, and The Interpretation of Research Results. Cambridge University Press.

Foji, S. (2015). The Study of The Effect of Guided Imagery On Pain, Anxiety and Some Other Hemodynamic Factors In Patients Undergoing Coronary Angiography. Complementary Therapies in Clinical Practice, 5.

Gholamreza, L \& Aziz, R. (2016). Positive And Negative Motivational Self-Talk Affect Learning Of Soccer Kick In Novice Players, Mediated By Anxiety. International Journal Of Humanities And Cultural Studies, 2356-5926.

Hoffman, S. L., \& Hanrahan, S. J. (n.d.). Mental Skills for Musicians: Managing Music Performance Anxiety and Enhancing Performance. 12.

Khiyarusoleh, U., \& Pd, M. (2016). Konsep Dasar Perkembangan Kognitif Pada Anak Menurut Jean Piaget. 5(1), 10.

Lin, M.-F., Hsieh, Y.-J., Hsu, Y.-Y., Fetzer, S., \& Hsu, M.-C. (2011). A Randomised Controlled Trial of The Effect of Music Therapy And Verbal Relaxation On Chemotherapy-Induced Anxiety: Intervention for Chemotherapy-Induced Anxiety. Journal of Clinical Nursing, 20(7-8), 988-999.

Lismadiana. (2014). Peranan Latihan Mental Dalam Pertandingan Bulutangkis. Fakultas Ilmu Keolahragaan Universitas Negeri Yogyakarta: Yogyakarta, 1-15

Liu, K., Chen, Y., Wu, D., Lin, R., Wang, Z., \& Pan, L. (2020). Effects of Progressive Muscle Relaxation On Anxiety And Sleep Quality In Patients With COVID-19. Complementary Therapies in Clinical Practice, 39, 101132.

Mizrahi, M. C., Reicher-Atir, R., Levy, S., Haramati, S., Wengrower, D., Israeli, E., \& Goldin, E. (2012). Effects of Guided Imagery With Relaxation Training on Anxiety and Quality of Life Among Patients With Inflammatory Bowel Disease. Psychology \& Health, 27(12), 1463-1479.

Nevid, J. S., Rathus, S. A., \& Greene, B. (2014). Abnormal Psychology In A Changing World (Nineth edition). Pearson. 
Nurfalah, R. T., Ugelta, S., \& Imanudin, I. (2016). Pengaruh Imajery Training terhadap Keterampilan Hasil Shooting Sepak Bola di SSB Java Putra Yudha. Jurnal Terapan Ilmu Keolahragaan, 1(1), 40.

Pan, L., Zhang, J., \& Li, L. (2012). Effects of Progressive Muscle Relaxation Training on Anxiety and Quality of Life of Inpatients With Ectopic Pregnancy Receiving Methotrexate Treatment: Progressive Muscle Relaxation For Ectopic Pregnancy. Research in Nursing $\mathcal{E}$ Health, 35(4), 376-382.

Premananda, S. S., \& Bhowmik, D. S. K. (n.d.). Effect of Psychological Skills Training Program on State and Trait Anxiety of Soccer Players. International Journal of Physiology, 4.

Shamekhi, A., Tadayonfar, M., Rastaghi, S., \& Molavi, M. (2019). Comparison of the Effect of Video Education and Guided Imagery on Patient Anxiety Before Endoscopy. Biomedical Research, 30(1).

Sekeroglu, M. Ö. (2017). Examining the Pre- and Post-Competition State Anxiety Levels of Sportswomen of the Dutch Women's Volleyball National Team. Journal of Education and Training Studies, 5(13).

Song, Q.-H., Xu, R.-M., Zhang, Q.-H., Ma, M., \& Zhao, X.-P. (n.d.). Relaxation Training During Chemotherapy for Breast Cancer Improves Mental Health and Lessens Adverse Events. 6.

Tavakolizadeh, J., Pahlavan, M., Basirimoghadam, M., \& Kianmehr, M. (2018). Effects of Guided Imagery on Anxiety and Physiological Indicators in In-patients with Acute Coronary Syndrome. Journal of Pharmaceutical Research International, 23(5), 1-8.

Weinberg, R. S., \& Gould, D. (2011). Foundations of Sport and Exercise Psychology (5th ed). Human Kinetics.

Yilmaz, S. G., Arslan, S., \& Arslan, S. (2015). Effects of Progressive Relaxation Exercises on Anxiety and Comfort of Turkish Breast Cancer Patients Receiving Chemotherapy. Asian Pacific Journal of Cancer Prevention, 16(1), 217-220.

Zhao, L., Wu, H., Zhou, X., Wang, Q., Zhu, W., \& Chen, J. (2012). Effects of Progressive Muscular Relaxation Training on Anxiety, Depression and Quality of Life of Endometriosis Patients Under Gonadotrophin-Releasing Hormone Agonist Therapy. European Journal of Obstetrics \& Gynecology and Reproductive Biology, 162(2), 211-215.

Zhou, K. (2014). A Slinical Randomized Controlled Trial of Music Therapy and Progressive Muscle Relaxation Training in Female Breast Cancer Patients After Radical Mastectomy: Results on Depression, Anxiety and Length of Hospital Stay. 6.

\begin{tabular}{|l|l|l|l|l|}
\hline Submit & Review & Revisi & Diterima & Publis \\
\hline $11-02-2021$ & 26-03-2021 sd 27-04-2021 & $30-04-2021$ & $02-05-2021$ & $13-06-2021$ \\
\hline
\end{tabular}

Prastika Prima Nugraheni, Ananta Yudiarso

Universitas Surabaya

Email : primaprastika@gmail.com, ananta@staff.ubaya.ac.id 